\title{
Production of glass-ceramics from heavy metal gypsum and pickling sludge
}

\author{
D. A. Pan - L. J. Li • J. Yang $\cdot$ J. B. Bu • \\ B. Guo $\cdot$ B. Liu $\cdot$ S. G. Zhang $\cdot$ A. A. Volinsky
}

Received: 30 September 2014/Revised: 4 December 2014/ Accepted: 6 January 2015/Published online: 24 February 2015

(C) Islamic Azad University (IAU) 2015

\begin{abstract}
The aim of this investigation was to propose a preparation method of glass-ceramics derived from heavy metal gypsum and pickling sludge, as well as stabilization of $\mathrm{Pb}, \mathrm{Zn}, \mathrm{Cd}, \mathrm{As}, \mathrm{Hg}, \mathrm{Cr}$ and $\mathrm{Ni}$ heavy metals. The process consists of the following two stages: the desulfurization of heavy metal gypsum and the preparation of glass-ceramics. Heavy metal gypsum was desulfurized by excess glass powder at 1,473 $\mathrm{K}$ and formed calcium silicate and silicon dioxide as intermediate products. The intermediate products, pickling sludge and small amounts of $\mathrm{CaO}$ and $\mathrm{MgO}$ were used as major raw materials for preparing parent glass. Glass-ceramics was produced by conventional heating method, which included a nucleation stage (973 K, $2 \mathrm{~h}$ ) and a crystallization stage $(1,173 \mathrm{~K}, 1 \mathrm{~h})$. The main crystalline phase of the obtained glass-ceramics is akermanite $\left(\mathrm{Ca}_{2} \mathrm{MgSi}_{2} \mathrm{O}_{7}\right)$. A high microhardness of $5.3 \mathrm{GPa}$ and a bending strength of $206 \mathrm{MPa}$, as well as a water absorption lower than $0.13 \%$ were obtained. The leaching of toxic elements in glass-ceramics was much lower than the Environmental Protection Agency 1311 method requirement.
\end{abstract}

Keywords Heavy metal gypsum · Pickling sludge · Glass-ceramics · Desulfurization

D. A. Pan $(\bowtie)$ - L. J. Li · J. Yang · J. B. Bu · B. Guo - B. Liu · S. G. Zhang

Institute of Advanced Materials and Technology, University of Science and Technology Beijing, Beijing 100083, People's Republic of China

e-mail: pandean@mater.ustb.edu.cn

A. A. Volinsky

Department of Mechanical Engineering, University of South Florida, Tampa, FL 33620, USA

\section{Introduction}

Pickling sludge is a product of the stainless steel pickling waste liquor disposed by the lime neutralization precipitation process. Due to the high concentration of $\mathrm{Cr}$ and $\mathrm{Ni}$, pickling sludge was listed in the national hazardous waste list (HW17, China). The conventional sludge disposal methods such as landfill and incineration may pollute the environment; thus, many new physicochemical and biological treatments (Merrylin et al. 2013; Uan et al. 2013; Kavitha et al. 2014a, 2014b; Uma Rani et al. 2014) are proposed to reduce the sludge production. However, there are few studies on how to recycle the pickling sludge which has rich calcium and iron resources. Hence, an advanced and environmentally friendly way of recycling pickling sludge is required. Gypsum $\left(\mathrm{CaSO}_{4} \cdot 2 \mathrm{H}_{2} \mathrm{O}\right)$ containing heavy metals is a solid waste from the lead and zinc production processes of the metallurgical industry. In the Zhuzhou city of China, the heavy metal gypsum is usually piled up in the cropland. However, metals, including lead, arsenic, zinc, cadmium, mercury, chromium and nickel can cause significant damage to the environment (Bååth 1989; Leyval et al. 1997; Nagajyoti et al. 2010; Wu et al. 2010; Tangahu et al. 2011) as a result of their mobility and solubility (Mulligan et al. 2001). These toxic elements in contaminated cropland can end up in the plants and transferred to the food chain, eventually accumulating into the human body, endangering human health, since these elements have been well established as toxic for living systems (Peralta-Videa et al. 2009). Therefore, effective and safe reuse of the heavy metal gypsum and pickling sludge, especially stabilizing and storing heavy metals, is a matter of serious concern and needs to be addressed.

Glass-ceramics are polycrystalline materials with fine microstructure produced by controlled crystallization (devitrification) of glass (Rawlings et al. 2006). Glass- 
ceramics has fine-grained structure, good mechanical properties and randomly oriented crystals with some residual glass without voids (Sun et al. 2001). Therefore, glass-ceramics is regarded as a new type of building material and can be used for storage of hazardous waste.

The main components of the pickling sludge are calcium fluoride and ferric oxide, which are considered to be good nucleating agents in the production of glass-ceramics (Cheng et al. 2006). Heavy metal gypsum is a good source for $\mathrm{CaO}$. Therefore, pickling sludge and heavy metal gypsum can be used as raw material for $\mathrm{Fe}_{2} \mathrm{O}_{3}, \mathrm{CaF}_{2}$ and $\mathrm{CaO}$ sources, respectively, in the production of glassceramics. In this way, toxic elements in pickling sludge and waste gypsum can be stabilized and solidified in glassceramics.

However, if the heavy metal gypsum is directly used for the preparation of glass-ceramics, sulfur dioxide gas formed in gypsum desulfurization process is easily volatized at high melting temperature, which can corrode equipment and pollute the environment. If melting temperature is lower, sulfur dioxide gas may remain in the glass liquid and form micropores in the parent glass, which has a negative effect on the mechanical properties of glassceramics. To avoid this problem, the waste gypsum should be desulfurized first.

There are several gypsum decomposition methods. The most common methods are using reduction (Van der Merwe et al. 1999; Ma et al. 2010) and/or reducing atmosphere (Diaz-Bossio et al. 1985; Kuusik et al. 1985) to decompose gypsum. However, these methods have high requirements for the reaction atmosphere and easily form sulfur by-products. In order to reduce the requirement of experimental conditions, heavy metal gypsum desulfurization by excessive amounts of glass powder in air is proposed in this work. The intermediate products calcium silicate and silicon dioxide can be directly used in the subsequent preparation of glass-ceramics. Currently, there have been few studies in this field.

The objective of this study was to propose a preparation method of glass-ceramics derived from heavy metal gypsum and pickling sludge, as well as stabilization of $\mathrm{Pb}, \mathrm{Zn}$, $\mathrm{Cd}$, As, $\mathrm{Hg}, \mathrm{Cr}$ and $\mathrm{Ni}$ heavy metals. The research was carried out from May 2014 to July 2014 in the Institute of Advanced Materials and Technology, University of Science and Technology, Beijing, China.

\section{Materials and methods}

Raw materials

Pickling sludge was provided by the Shanghai Baosteel Group Corporation (Shanghai, China). Heavy metal gypsum was collected from the Zhuzhou city in the Hunan province of China. Waste cullet was collected from the Beijing city in China. The collected solid wastes were ground into powder in a ball mill and sieved to less than $1 \mathrm{~mm}$. Then, the gypsum powder was dried at $573 \mathrm{~K}$ for $60 \mathrm{~min}$.

Chemical composition of the heavy metal gypsum, pickling sludge and waste cullet was characterized by X-ray florescence (XRF, Axios, PANaytical,The Netherlands). Leachability of the wastes was evaluated by the Environmental Protection Agency toxicity characteristic leaching procedure (TCLP, EPA method 1311) (USEPA 1990), using acetic acid $(2.88 \mathrm{pH})$ as the leaching agent at a liquid to solid ratio of 20:1. The filtrates were filtered with $0.45-\mu \mathrm{m}$ membranes for $18 \mathrm{~h}$, then acidified to the $\mathrm{pH}$ of 2 with $1 \mathrm{~N} \mathrm{HNO}_{3}$ and analyzed for $\mathrm{Pb}, \mathrm{Zn}$, $\mathrm{Cd}, \mathrm{As}, \mathrm{Hg}, \mathrm{Cr}$ and $\mathrm{Ni}$ by the inductively coupled plasma (ICP, iCAP 6300, Thermo Fisher Scientific, US) method.

Heavy metal gypsum desulfurization process

Heavy metal gypsum and glass powder were mixed up at the silicon to calcium ratio of $0.8,1.5,2.0$ and 2.5 , respectively. The four groups of samples were heated in air at $1,173 \mathrm{~K}$, with a heating rate of $10 \mathrm{~K} / \mathrm{min}$ and kept at $1,173 \mathrm{~K}$ for $2 \mathrm{~h}$. In addition, the samples with silicon to calcium ratio of 2.5 were heated at 1,173, 1,273, 1,373 and $1,473 \mathrm{~K}$ for $2 \mathrm{~h}$, respectively.

The samples and products were completely dissolved in the mixture of nitric, hydrochloric, hydrofluoric and perchloric acids, and then, the concentration of sulfur in mixtures and products was determined by the ICP.

The desulfurization rate $(\zeta)$ of the heavy metal gypsum can be calculated as:

$\zeta=\frac{m_{0} c_{0}-m_{1} c_{1}}{m_{0} c_{0}} \times 100 \%$

where $m_{0}$ is the raw mix mass in $\mathrm{g}, m_{1}$ is the product mass in $\mathrm{g} ; c_{0}$ and $c_{1}$ is the mass percent of sulfur in the raw mix and in the product, respectively.

Preparation and properties of glass-ceramics

The intermediate product obtained from the sample with silicon to calcium ratio of 2.5 and heated at $1,473 \mathrm{~K}$ was used as raw material for the preparation of glass-ceramics. The intermediate product $(64.96 \mathrm{wt} \%)$, pickling sludge (16.45 wt \%), $\mathrm{CaO}(7.41 \mathrm{wt} \%)$ and $\mathrm{MgO}(11.18 \mathrm{wt} \%)$ were blended and melted in corundum crucible in a muffle furnace at $1,733 \mathrm{~K}$ with a heating rate of $7 \mathrm{~K} / \mathrm{min}$. After $2.5 \mathrm{~h}$, the melted glass liquid was rapidly poured on an iron plate preheated to $873 \mathrm{~K}$ in advance, then kept at $873 \mathrm{~K}$ for 
30 min to remove internal stresses. Parent glass was obtained after cooling to room temperature.

The parent glass was sintered in air at nucleation temperature of $973 \mathrm{~K}$ for $2 \mathrm{~h}$ with a heating rate of $10 \mathrm{~K} / \mathrm{min}$ and crystallization temperature of $1,173 \mathrm{~K}$ for $1 \mathrm{~h}$ with a heating rate of $5 \mathrm{~K} / \mathrm{min}$, then the glass-ceramics was obtained.

The obtained glass-ceramics was characterized by a series of tests. The main crystalline phase was identified by X-ray diffraction (XRD, Ultima IV, Cu-Ka, Rigaku, Japan). The microstructure of the fracture surface of the sample etched with HF $0.1 \mathrm{~N}$ for $30 \mathrm{~s}$ was observed by scanning electron microscopy (SEM, Quanta 250, FEI, USA) and gold covered before microscopic observations. The microhardness was measured five times by the microhardness tester (MH-6, China) with a load of $300 \mathrm{~g}$ and a loading time of $10 \mathrm{~s}$. The obtained glass-ceramics was cut into five samples of the same dimension of $3 \times 4 \times 40 \mathrm{~mm}^{3}$, used for the bending strength test. The bending strength of each sample was determined by the three-point bending strength tester (CDW-5, China). Water absorption was measured after 3-h immersion in boiling distilled water, according to the Chinese National Standard GB/T 3299-2011 (2012). The leaching behavior of heavy metals in the glass-ceramics was determined following the EPA TCLP.

The water absorption $(W)$ of the heavy metal gypsum can be calculated as:

$W=\frac{m_{3}-m_{2}}{m_{2}} \times 100 \%$

where $m_{2}$ is the glass-ceramics mass without immersion in $\mathrm{g}$ and $m_{3}$ is the glass-ceramics mass after immersing in boiling water for $3 \mathrm{~h}$ in $\mathrm{g}$.

\section{Results and discussion}

Characterization of pickling sludge and heavy metal gypsum

Chemical composition of the heavy metal gypsum, pickling sludge and waste cullet is listed in Table 1 . The main gypsum components are $\mathrm{CaO}, \mathrm{SO}_{3}(42.02$ and $37.01 \mathrm{wt} \%$, respectively, mainly as $\left.\mathrm{CaSO}_{4}\right), \mathrm{SiO}_{2}(3.08 \mathrm{wt} \%), \mathrm{Fe}_{2} \mathrm{O}_{3}$ (6.11 wt\%), along with small amounts of heavy metal oxides (about $3.51 \mathrm{wt} \%$ ). The pickling sludge main chemical components are $\mathrm{Fe}_{2} \mathrm{O}_{3}(23.19 \mathrm{wt} \%), \mathrm{CaO}$ and $\mathrm{F}$ (31.95 and $18.72 \mathrm{wt} \%$, respectively, mainly as $\mathrm{CaF}_{2}$ ). Moreover, the concentration of $\mathrm{Cr}_{2} \mathrm{O}_{3}$ and $\mathrm{NiO}$ in pickling sludge is 4.55 and $1.67 \mathrm{wt} \%$, respectively. The cullet main chemical components are $\mathrm{SiO}_{2}(68.30 \mathrm{wt} \%)$ and $\mathrm{Na}_{2} \mathrm{O}$ (14.37 wt \%).

TCLP leachate analysis data are given in Table 2. The leaching of $\mathrm{Cd}$ (35.145 ppm) in the gypsum is much higher than the $1 \mathrm{ppm}$ threshold, prescribed in the EPA method 1311. High Zn concentration of $263.433 \mathrm{ppm}$ was observed in the leachate. In addition, high concentration of $\mathrm{Cr}$ (159.8 ppm) and $\mathrm{Ni}(192.2 \mathrm{ppm})$ was also observed in the leachate of the pickling sludge.

Silicon/calcium ratio $(\mathrm{Si} / \mathrm{Ca})$ effect

on the desulfurization process

Four groups of samples with different silicon to calcium ratios of $0.8,1.5,2.0$ and 2.5 were heated at $1,173 \mathrm{~K}$. Figure 1 shows the XRD patterns of the products obtained at different silicon to calcium ratios. Every sample has already started to decompose at $1,173 \mathrm{~K}$. As the content of glass powder increased, the amounts of

Table 1 Chemical composition of the heavy metal gypsum, the pickling sludge and waste cullet (wt $\%$ )

\begin{tabular}{|c|c|c|c|c|c|c|c|c|c|c|c|c|c|}
\hline Composition & $\mathrm{CaO}$ & $\mathrm{SO}_{3}$ & $\mathrm{SiO}_{2}$ & $\mathrm{~F}$ & $\mathrm{Na}_{2} \mathrm{O}$ & $\mathrm{As}_{2} \mathrm{O}_{3}$ & $\mathrm{Fe}_{2} \mathrm{O}_{3}$ & $\mathrm{ZnO}$ & $\mathrm{PbO}$ & $\mathrm{CdO}$ & $\mathrm{HgO}$ & $\mathrm{Cr}_{2} \mathrm{O}_{3}$ & $\mathrm{NiO}$ \\
\hline Waste gypsum & 42.02 & 37.01 & 3.08 & 2.49 & 2.17 & 0.28 & 6.11 & 2.71 & 0.30 & 0.19 & 0.01 & - & 0.02 \\
\hline Pickling sludge & 31.95 & 3.98 & 8.45 & 18.72 & 1.58 & - & 23.19 & 0.03 & - & - & - & 4.55 & 1.67 \\
\hline Waste cullet & 9.04 & 0.37 & 68.30 & - & 14.37 & - & 0.59 & - & - & - & - & 0.03 & - \\
\hline
\end{tabular}

Table 2 Concentration of toxic elements in the leachate (ppm)

\begin{tabular}{lllllll}
\hline & $\mathrm{Pb}$ & $\mathrm{Zn}$ & $\mathrm{Cd}$ & $\mathrm{As}$ & $\mathrm{Hg}$ & $\mathrm{Cr}$ \\
\hline Waste gypsum & 0.018 & 263.433 & 35.145 & 0.073 & 0.043 & 0.008 \\
Pickling sludge & 0.072 & 3.910 & 0.500 & 0.224 & - & 0.240 \\
Glass-ceramics & 0.032 & 6.360 & 0.527 & 0.214 & - & 159.8 \\
Toxicity threshold & 5.00 & - & 1.00 & 5.00 & 0.20 & 0.317 \\
\hline
\end{tabular}




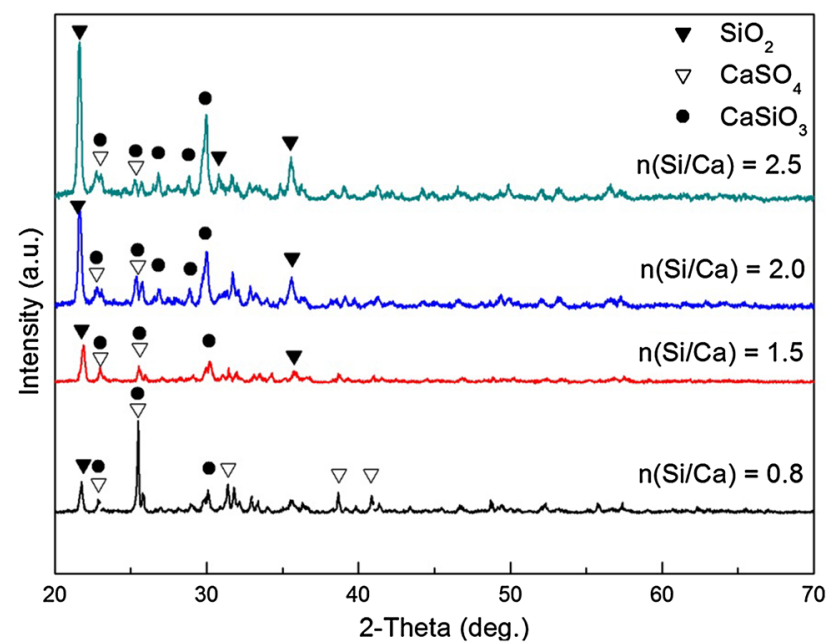

Fig. 1 XRD patterns of the products obtained at different silicon to calcium ratios

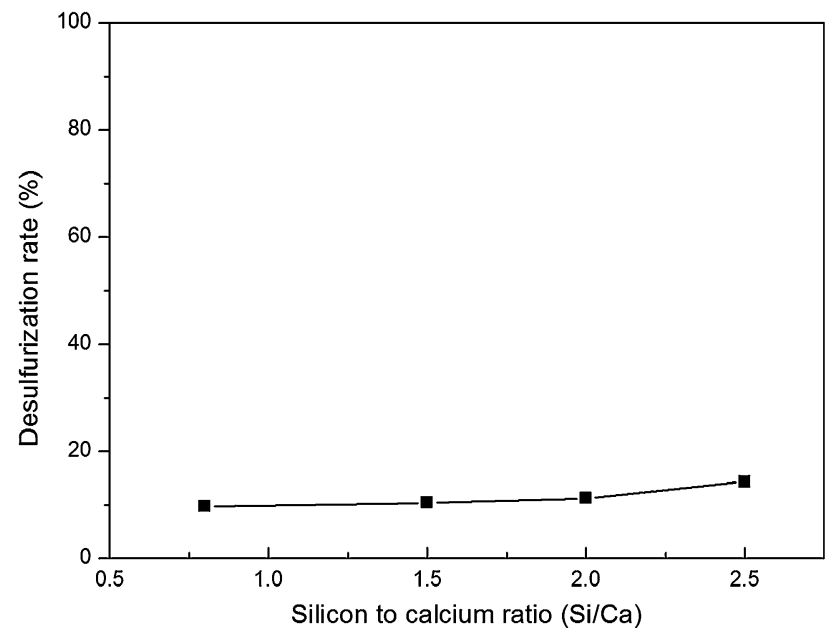

Fig. 2 Desulfurization rates of samples at different silicon to calcium ratios

$\mathrm{SiO}_{2}$ and $\mathrm{CaSiO}_{3}$ in products were also improved. The corresponding desulfurization rates of the four samples were calculated, shown in Fig. 2. The desulfurization rates are slightly improved with the silicon to calcium ratio increase. When the silicon to calcium ratio is 0.8 , the sample desulfurization rate is $9.7 \%$, while desulfurization rate is increased to $14.3 \%$ at the silicon to calcium ratio of 2.5 . This is because the reaction between $\mathrm{CaSO}_{4}$ and $\mathrm{SiO}_{2}$ occurred at the contact points of the two kinds of powder particles. With the increase of silicon to calcium ratio, the possibility of a $\mathrm{CaSO}_{4}$ particle surrounded by the glass powder becomes higher (Matsuya and Yamane 1981). Therefore, the contact area between gypsum and glass powder could increase with the content of glass powder.

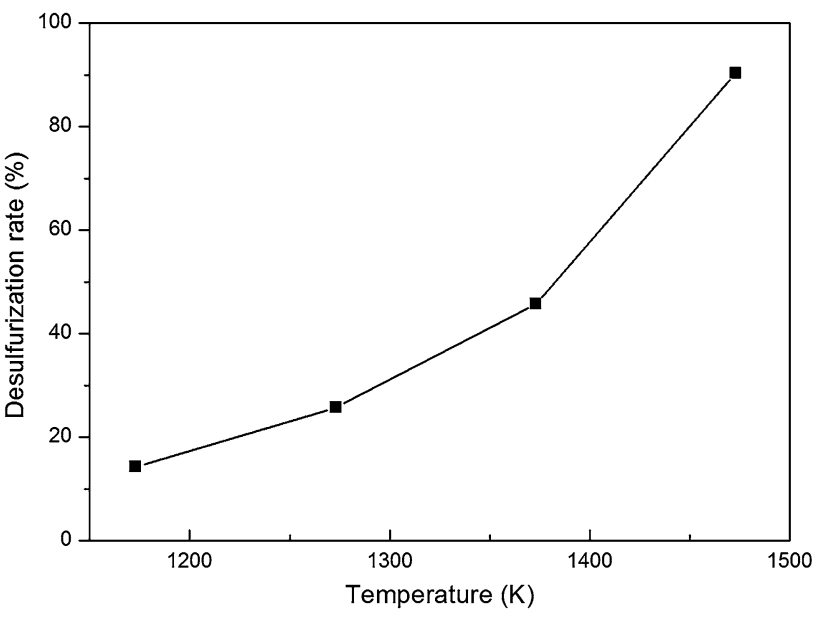

Fig. 3 Desulfurization rates of samples at different temperatures

If the silicon to calcium ratio further increase, calcium content of the raw materials will reduce accordingly. Therefore, more pure calcium oxide should be added in the subsequent process of the preparation of glass-ceramics, and the material cost will also increase. However, the desulfurization of heavy metal gypsum is not sensitive to silicon to calcium ratio; hence, there is no need to increase the silicon to calcium ratio and material cost further. Silicon to calcium ratio of 2.5 is appropriate and can be used in the subsequent experiment.

Temperature effect on the desulfurization process

Four groups of samples with silicon to calcium ratio of 2.5 were heated at $1,173,1,273,1,373$ and $1,473 \mathrm{~K}$, respectively. The desulfurization rates of the samples were calculated, shown in Fig. 3. The desulfurization rates are significantly improved with the temperature increase, i.e., $14.3,25.7,45.7$ and $90.3 \%$ at 1,173, 1,273, 1,373, and $1,473 \mathrm{~K}$, respectively. Higher desulfurization rate of heavy metal gypsum means less sulfur dioxide gas formed in the subsequent preparation of glass-ceramics. Since sulfur dioxide gas may corrode equipment and form micropores in the parent glass, high desulfurization rate is good for the preparation of glass-ceramics. The desulfurization rate at $1,473 \mathrm{~K}$ is relatively high (more than $90 \%$ ), and there is no need to increase the heating temperature and energy consumption further. Therefore, the decomposition product at $1,473 \mathrm{~K}$ can be used to prepare glass-ceramics.

With the temperature increase, the glass viscosity is lower. Moreover, the complex ion $\left(\mathrm{Si}_{x} \mathrm{O}_{y}\right)^{z-}$ in glass can be depolymerized to small complex anion group by the fluoride ions in gypsum, which breaks the glass network structure, reduces the viscous flow activation energy and increases the rate of mass transfer in the liquid phase, thus accelerates material diffusion and promotes the reaction 


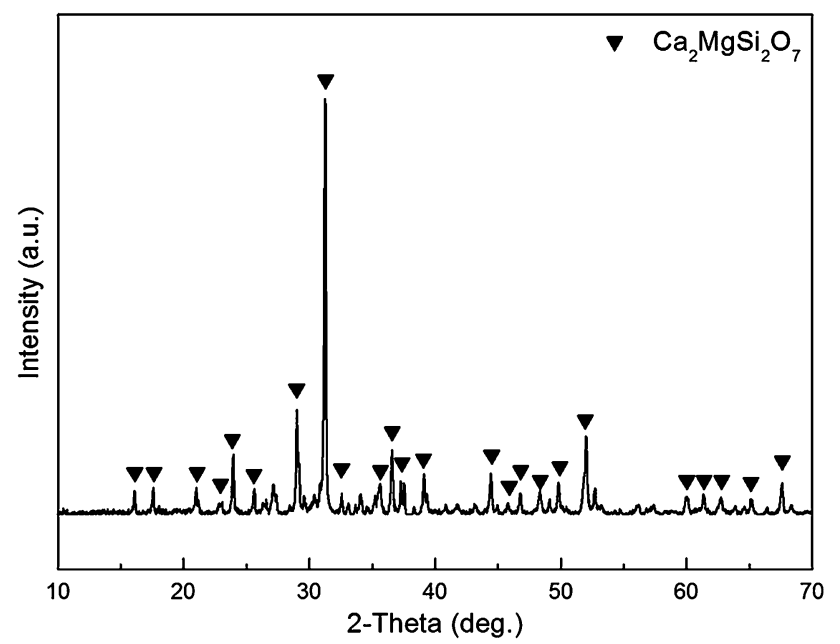

Fig. 4 XRD pattern of the obtained glass-ceramics

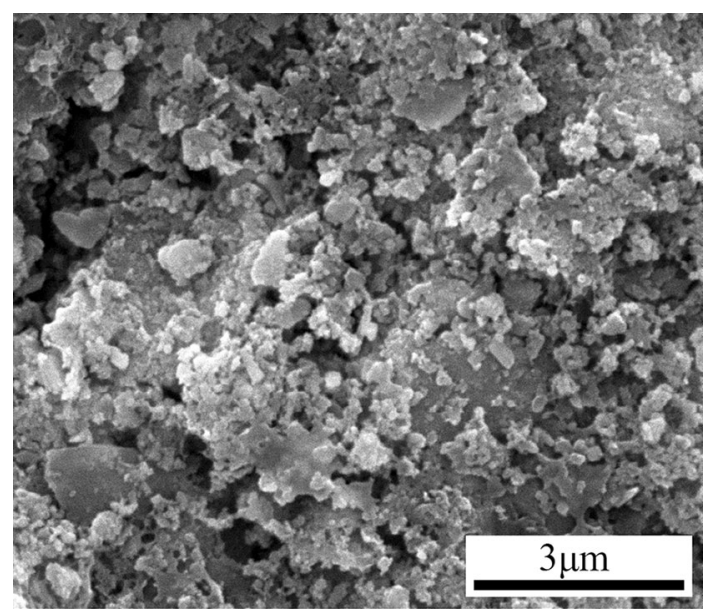

Fig. 5 SEM micrograph of the obtained glass-ceramics

( $\mathrm{Lu}$ 2010). Therefore, the combination of rising the temperature with the fluoride ion may translate the solid-solid reaction between $\mathrm{CaSO}_{4}$ and $\mathrm{SiO}_{2}$ into the solid-liquid reaction. Thus, diffusion along with the reaction between $\mathrm{CaSO}_{4}$ and $\mathrm{SiO}_{2}$ is accelerated and the desulfurization rate increased, significantly promoting gypsum desulfurization.

Properties of glass-ceramics

The XRD pattern of the obtained glass-ceramics is shown in Fig. 4, where the main crystalline phase is akermanite $\left(\mathrm{Ca}_{2} \mathrm{MgSi}_{2} \mathrm{O}_{7}\right)$. The main crystalline phase is determined by the mass ratio of calcium oxide, magnesium oxide and silicon dioxide of raw materials. SEM micrographs of the sample are shown in Fig. 5. The glass phase of the glassceramics decreased dramatically. Crystallization is induced by bulk nucleation, since crystallization occurs throughout the entire sample volume (Leroy et al. 2001; Liu et al.
Table 3 Measured properties of glass-ceramics

\begin{tabular}{ll}
\hline Property & \\
\hline Microhardness & $5.3 \pm 0.02 \mathrm{GPa}$ \\
Bending strength & $206 \pm 15 \mathrm{MPa}$ \\
Water absorption & $0.13 \%$ \\
\hline
\end{tabular}

2009), giving rise to the three-dimensional connectivity and quite a large amount of fine-grained $(0.2-1 \mu \mathrm{m})$ microstructure, which has higher strength and fracture toughness, since the expansion of the micro cracks was hindered by a large number of grain boundaries. The threedimensional connectivity structure was generated by the spinodal decomposition and the split phase. The microcrystal fluoride was in the nucleation center of glass when using fluoride as the nucleating agent, and the formation temperature of fluoride crystal nucleus was usually lower than crystal growth temperature; therefore, the glassceramics with fluoride as nucleating agent has a large number of fine-grained crystals, rather than a small number of coarse grains (Cheng et al. 2006).

Other properties, such as microhardness, bending strength and water absorption of glass-ceramics are listed in Table 3. A high microhardness of $5.3 \pm 0.02 \mathrm{GPa}$ and a water absorption lower than $0.13 \%$ were obtained. High bending strength is an important mechanical property of architectural glass-ceramics, and the average three-point bending strength is $206 \mathrm{MPa}$. These excellent mechanical properties are caused by the three-dimensional connectivity and quite a large amount of fine-grained microstructure.

TCLP leachate analysis data are given in Table 2. For the glass-ceramics from heavy metal gypsum and pickling sludge, the concentrations of toxic elements in leachate are much less than the thresholds and meet the TCLP standard, especially $\mathrm{Cd}, \mathrm{Cr}$ and $\mathrm{Ni}$ metals, of which the leaching toxicities in raw materials exceeded the standard. Therefore, $\mathrm{Pb}, \mathrm{Zn}, \mathrm{Cd}, \mathrm{As}, \mathrm{Hg}, \mathrm{Cr}$, Ni heavy metals in pickling sludge and waste gypsum can be successfully stabilized and solidified in glass-ceramics.

\section{Conclusion}

A preparation method of glass-ceramics derived from heavy metal gypsum and pickling sludge, as well as stabilization of $\mathrm{Pb}, \mathrm{Zn}, \mathrm{Cd}$, As, $\mathrm{Hg}, \mathrm{Cr}$ and Ni heavy metals was proposed in this work. First, heavy metal gypsum was desulfurized by glass powder at 1,473 K and kept 1,473 K for $2 \mathrm{~h}$, with silicon to calcium ratio of 2.5 . The desulfurization rate was more than $90 \%$. Second, the intermediate product from the first step and pickling sludge were used as 
major raw materials of glass-ceramics, using $\mathrm{CaO}$ and $\mathrm{MgO}$ as composite additives. The obtained fine-grained glass-ceramics has good mechanical properties. A high microhardness of $5.3 \mathrm{GPa}$ and a bending strength higher than $206 \mathrm{MPa}$ were obtained. Water absorption was lower than $0.13 \%$. Moreover, $\mathrm{Pb}, \mathrm{Zn}, \mathrm{Cd}, \mathrm{As}, \mathrm{Hg}, \mathrm{Cr}$ and $\mathrm{Ni}$ heavy metals in pickling sludge and waste gypsum can be successfully stabilized and solidified in glass-ceramics and meet the TCLP standard.

This combined process on disposing heavy metal gypsum and pickling sludge, as well as making heavy metals harmless and stabilized, is an effective potential method for industrial production.

Acknowledgments This work was supported by the Beijing Nova program (Z141103001814006), by the National Key Technology R\&D Program (2012BAC12B05 and 2012BAC02B01), by the National Natural Science Foundation of China (51174247 and U1360202) and by the National High-Tech Research and the Development Program of China (2012AA063202).

\section{References}

Bååth E (1989) Effects of heavy metals in soil on microbial processes and populations (a review). Water Air Soil Pollut 47:335-379

Cheng Jinshu, Li Hong, Tang Liyin, He Feng (2006) Glass-ceramic. Chemical Industry Press, Beijing

Diaz-Bossio LM, Squier SE, Pulsifer AH (1985) Reductive decomposition of calcium sulfate utilizing carbon monoxide and hydrogen. Chem Eng Sci 40:319-324

Kavitha S, Jayashree C, Kumar SA, Kaliappan S, Banu JR (2014a) Enhancing the functional and economical efficiency of a novel combined thermo chemical disperser disintegration of waste activated sludge for biogas production. Bioresour Technol 173:32-41

Kavitha S, Kumar SA, Kaliappan S, Yeom IT, Banu JR (2014b) Improving the amenability of municipal waste activated sludge for biological pretreatment by phase-separated sludge disintegration method. Bioresour Technol 169:700-706

Kuusik R, Salkkonen P, Niinistö L (1985) Thermal decomposition of calcium sulphate in carbon monoxide. J Therm Anal 30:187-193

Leroy C, Ferro M, Monteiro R, Fernandes M (2001) Production of glass-ceramics from coal ashes. J Eur Ceram Soc 21:195-202

Leyval C, Turnau K, Haselwandter K (1997) Effect of heavy metal pollution on mycorrhizal colonization and function: physiological, ecological and applied aspects. Mycorrhiza 7:139-153
Liu H, Lu H, Chen D, Wang H, Xu H, Zhang R (2009) Preparation and properties of glass-ceramics derived from blast-furnace slag by a ceramic-sintering process. Ceram Int 35:3181-3184

$\mathrm{Lu}$ A (2010) An introduction to inorganic non-metallic materials. Central south university Press, Changsha

Ma L, Ning P, Zheng S, Niu X, Zhang W, Du Y (2010) Reaction mechanism and kinetic analysis of the decomposition of phosphogypsum via a solid-state reaction. Ind Eng Chem Res 49:3597-3602

Matsuya S, Yamane M (1981) Decomposition of gypsum bonded investments. J Dent Res 8:1418-1423

Merrylin J, Kaliappan S, Kumar SA, Yeom I, Rajesh BJ (2013) Effect of extracellular polymeric substances on sludge reduction potential of Bacillus licheniformis. Int J Environ Sci Technol 10:85-92

Mulligan C, Yong R, Gibbs B (2001) Remediation technologies for metal-contaminated soils and groundwater: an evaluation. Eng Geol 60:193-207

Nagajyoti P, Lee K, Sreekanth T (2010) Heavy metals, occurrence and toxicity for plants: a review. Environ Chem Lett 8:199-216

Peralta-Videa JR, Lopez ML, Narayan M, Saupe G, GardeaTorresdey J (2009) The biochemistry of environmental heavy metal uptake by plants: implications for the food chain. Int $\mathrm{J}$ Biochem Cell Biol 41:1665-1677

Rawlings RD, Wu J, Boccaccini A (2006) Glass-ceramics: their production from wastes-a review. J Mater Sci 41:733-761

Sun DD, Tay JH, Cheong HK, Leung DLK, Qian G (2001) Recovery of heavy metals and stabilization of spent hydrotreating catalyst using a glass-ceramic matrix. J Hazard Mater 87:213-223

Tangahu BV, Sheikh Abdullah SR, Basri H, Idris M, Anuar N, Mukhlisin M (2011) A review on heavy metals (As, $\mathrm{Pb}$, and $\mathrm{Hg}$ ) uptake by plants through phytoremediation. Int J Chem Eng 2011. doi: $10.1155 / 2011 / 939161$

Uan D, Yeom I, Arulazhagan P, Banu JR (2013) Effects of sludge pretreatment on sludge reduction in a lab-scale anaerobic/anoxic/ oxic system treating domestic wastewater. Int J Environ Sci Technol 10:495-502

Uma Rani R, Adish Kumar S, Kaliappan S, Yeom IT, Rajesh Banu J (2014) Enhancing the anaerobic digestion potential of dairy waste activated sludge by two step sono-alkalization pretreatment. Ultrason Sonochem 21:1065-1074

USEPA TCLP (1990) EPA method 1311. Washington, US

Van der Merwe E, Strydom C, Potgieter J (1999) Thermogravimetric analysis of the reaction between carbon and $\mathrm{CaSO} 4 \cdot 2 \mathrm{H} 2 \mathrm{O}$, gypsum and phosphogypsum in an inert atmosphere. Thermochim Acta 340:431-437

Wu G, Kang H, Zhang X, Shao H, Chu L, Ruan C (2010) A critical review on the bio-removal of hazardous heavy metals from contaminated soils: issues, progress, eco-environmental concerns and opportunities. J Hazard Mater 174:1-8 